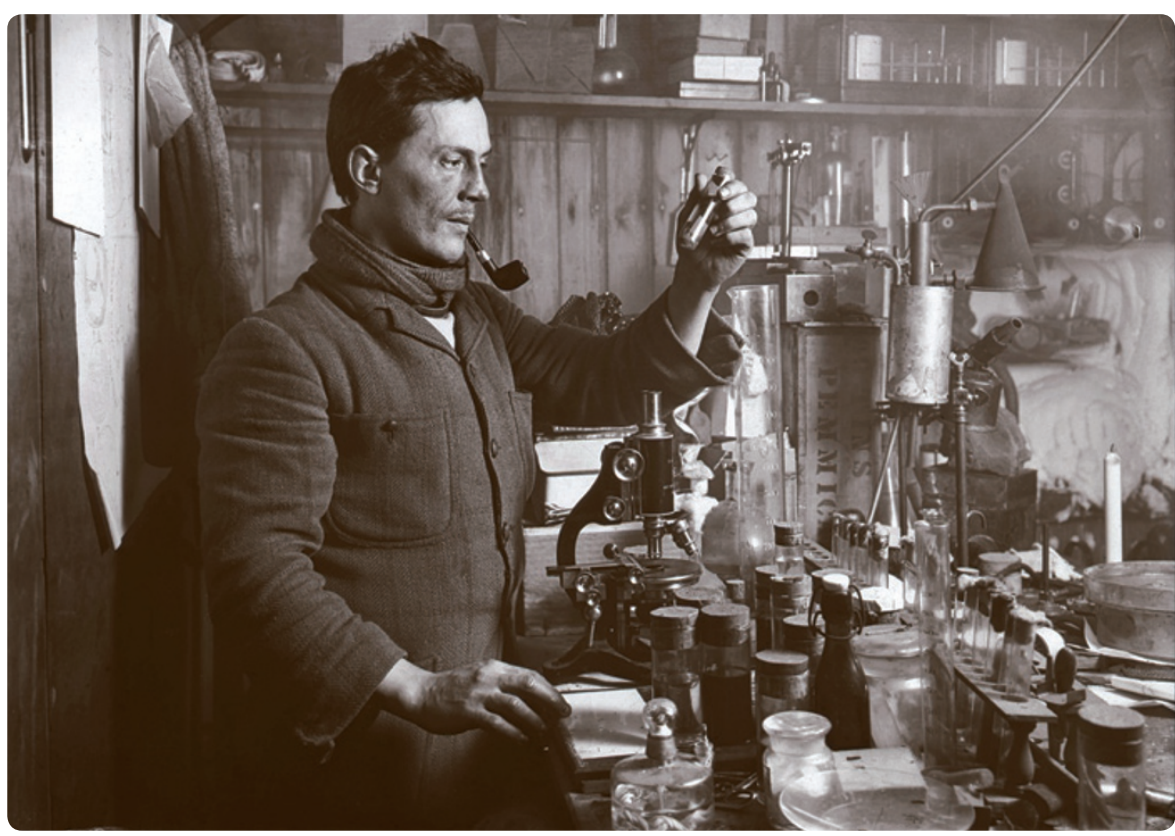

Biologist Edward Atkinson in the lab at Cape Evans hut, base camp of the Antarctic Terra Nova expedition. ANTARCTICA

\section{Scientists to the end}

\section{Colin Martin celebrates a London exhibition revealing the research legacy of Robert Scott's final journey.}

$\mathrm{I}$ $\mathrm{t}$ is one of the most poignant moments in polar history. One hundred years ago this week, British Antarctic Expedition leader Robert Falcon Scott and his four companions reached the spot where, 33 days previously, Roald Amundsen and his party had planted a Norwegian flag. All five members of Scott's party died while attempting to return to their base camp at Cape Evans.

That tragic outcome has tended to overshadow the expedition's scientific achievements. In Scott's Last Expedition, London's Natural History Museum aims to redress the balance. As curator Elin Simonsson explains, "We want people to know that Scott's British Antarctic Expedition was not simply a quest to reach the South Pole, but an important scientific expedition that carried out work across many fields."

Those fields included glaciology (then in its infancy), biology, magnetism, meteorology, chemistry and physics. The scientific team that participated in Scott's Terra Nova expedition of 1910-13 numbered 12 - the largest sent to the Antarctic at that time - including zoologist Edward Wilson, geologist T. Griffith Taylor and meteorologist George Simpson.

When the ship Terra Nova returned to England, it was laden with
Scott's Last Expedition

Natural History Museum, London.

20 January to 2 September 2012

These Rough Notes

Scott Polar Research Institute, Cambridge, UK. Until 5 May 2012

specimens of 2,109 animals, plants and fossils - with more than 401 new to science. Geological specimens (1,919 of which are in the museum's permanent collection) helped to construct knowledge of the continent. The meteorological data - the longest unbroken record of weather collected in the early twentieth century - provide baselines that are now used in assessing climate change.

The shore party of 25 men lived and worked in a wooden hut measuring 112 square metres (about half the area of a singles tennis court). Although the hut was equipped with scientific instruments, the scientists' real lab was the Antarctic. The exhibition includes a full-size representation of the hut with actual artefacts from the expedition on display, including scientific apparatus and (the original is preserved at Cape Evans), notebooks as well as a range of biological and geological specimens.

These include the shells of three eggs from the emperor penguin (Aptenodytes forsteri pictured), which contained embryos at different stages of development. Wilson, his assistant Apsley Cherry-Garrard and marine lieutenant Henry Bowers collected them under unimaginably harsh conditions, trudging to the penguin breeding colony at Cape Crozier - a trip immortalized by Cherry-Garrard in his 1922 book The Worst Journey in the World. The team's painstaking preservation and study of the embryos ultimately came to little, as theories about bird evolution from reptiles had changed by the time their report was published in 1934.

However, the fossils of the extinct plant Glossopteris indica, found by Scott and his final companions, provided important evidence that the climate of Antarctica once supported vegetation and was a part of the supercontinent Gondwana.

The expedition is also documented by photographs, many by photographer Herbert Ponting. These include an iconic image of Scott writing in his diary, and parasiticinfection specialist Edward Atkinson working at the bench. Similarly informative are Scott's own 'lost' photographs. Only a handful of the 120 images he took under Ponting's tutelage had been available until last year, when Wilson's great-nephew, polar historian David M. Wilson, published The Lost Photographs of Captain Scott (Little, Brown; 2011). The snowy panoramas and shots of expedition life help to reveal the daily realities of his last endeavour, while polar scientists still use the images for comparison with contemporary photographs to assess climate impacts.

A concurrent exhibition, These Rough Notes, is showing at the Scott Polar Research Institute in Cambridge, UK. It takes its title from a journal entry written by Scott shortly before his death - "These rough notes and

our dead bodies must tell the tale..." and displays personal papers of Scott and other expedition members. They record the heartbreaking poignancy of the polar party's death. But as the exhibition at the Natural History Museum shows, we need to reinforce the dual importance of this extraordinary expedition. "We want the scientific work to make the bagging of the Pole merely an item in the results," wrote Wilson at the expedition's outset. He didn't, of course, foresee that his own fate, and

that of Scott and other colleagues, would long eclipse an enduring scientific legacy that led to the publication of 81 papers.

Colin Martin is a writer based in London. e-mail:cmpubrel@aol.com 